\title{
PRÁTICAS HUMANIZADAS EM UMA CLÍNICA DE ONCOLOGIA NO INTERIOR DE SÃO PAULO
}

\author{
Douglas da Silva Nietto \\ Graduando de enfermagem do Centro Universitário de Itapira \\ E-mail:dnietto12@gmail.com
}

INTRODUÇÃO: A incidência de doenças oncológicas tem aumentado cada vez mais no Brasil, sendo estimado que estes casos ainda aumentem mais nos próximos anos. Segundo o Instituto Nacional do Câncer - INCA, o câncer só é superado por doenças cardiovasculares como causa mais incidente de óbito na população. A oncologia é um ramo da ciência que lida com tumores e câncer. A quimioterapia é a terapêutica utilizada com o objetivo de destruir ou bloquear o crescimento de células cancerosas. OBJETIVO: Evidenciar as práticas humanizadas realizadas em uma clínica de oncologia do interior de São Paulo e a importância destas ações para a melhoria do cuidado. MÉTODO: Trata-se de estudo descritivo do tipo relato de experiência das práticas de uma clínica oncológica, que conta com equipe interdisciplinar que realiza ações de humanização para os clientes assistidos por ela. Realizado levantamento das ações desenvolvidas no serviço de saúde e avaliado o impacto que elas trazem para um melhor desempenho na terapêutica da clientela. RESULTADOS: A assistência humanizada ao cliente oncológico deve favorecer o aparecimento de ambientes terapêuticos onde possam ser abordados sentimentos, esclarecer percepções e receber informações relacionadas ao tratamento. Auxiliando para que o indivíduo cuidado se torne parte ativa em seu processo terapêutico. Foi verificado que são realizadas nesta clínica 09 tipos de ações efetivas e contínuas que tem como objetivo uma assistência humanizada durante todo tratamento. Diante das ações de humanização desenvolvidas percebe-se que o paciente se apresenta mais afetivo, emocionalmente amparado e melhor acolhido pelo ambiente e pela equipe. Assim, conclui seu tratamento de forma positiva e menos angustiante. São realizadas ações como: a criação de ambiente acolhedor e climatizado, doações de lenços, musicoterapia, empréstimos de perucas para pacientes em tratamento, entre outras ações. São também realizados eventos anuais objetivando estimular a convivência social dos pacientes, tais como festa Junina e confraternização de final de ano, além de outros. CONCLUSÃO: O perfil do paciente oncológico requer um ambiente 
acolhedor e afetivo, dito isso observamos na pratica que a humanização se faz importante no dia-a-dia da clínica, uma vez que, esta promove o bem estar do paciente e melhor adaptação ao tratamento quimioterápico.

Palavras-chave: Oncologia. Humanização. Quimioterapia. 